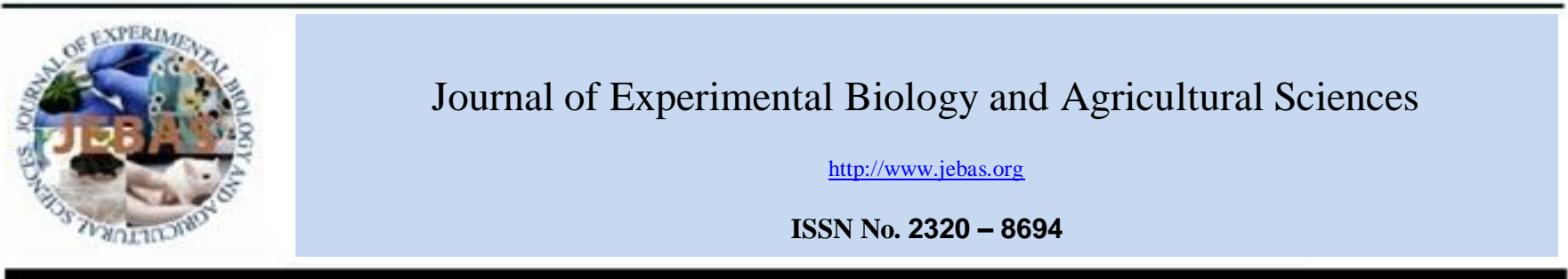

\title{
MOLECULAR AND FLORAL CHARACTERIZATION OF MAINTAINER AND RESTORERS IN NEWLY DEVELOPED RICE (Oryza sativa L.) HYBRIDS
}

\author{
R. Madhuri ${ }^{1 *}$, N. Shivakumar ${ }^{2}$, H. C. Lohithaswa ${ }^{3}$, R. Pavan $^{3}$ \\ ${ }^{1}$ Department of Genetics and Plant Breeding, University of Agricultural and Horticultural Sciences, Shivamogga, Karnataka - 577 204, India \\ ${ }^{2}$ Hybrid rice section, Zonal Agricultural Research Station, V. C. Farm, Mandya- 571 405, India \\ ${ }^{3}$ Department of Genetics and Plant Breeding, College of Agriculture, V. C. Farm, Mandya- 571 405, India
}

Received - December 17, 2018; Revision - January 17, 2019; Accepted - January 28, 2019

Available Online - February 5, 2019

DOI: http://dx.doi.org/10.18006/2019.7(1).34.41

\author{
KEYWORDS \\ Cytoplasmic male sterility \\ Maintainer \\ Pollen fertility \\ Restorer \\ Spikelet fertility \\ SSR markers
}

* Corresponding author

E-mail: madhu13madhuri@gmail.com (R. Madhuri)

Peer review under responsibility of Journal of Experimental Biology and Agricultural Sciences.

Production and Hosting by Horizon Publisher India [HPI] (http://www.horizonpublisherindia.in/).

All rights reserved.

\begin{abstract}
Hybrid rice is one of the successfully demonstrated technologies, which is feasible and readily adoptable for enhancing the rice production. But availability of stable cytoplasmic male sterility and fertility restoring system is vital for commercial exploitation of heterosis in rice. In the present study, seven testers were identified based on their pollen and spikelet fertility at Hybrid rice section, Mandya which were validated for fertility restoration (Rf) locus by four (RM 1, RM 6100, RM 6344 and RM 1108) reported linked SSR markers before hybridization with 10 CMS lines to develop 70 hybrids. All the four markers showed highly positive association with phenotypic fertility restoration and maintainer type allele. The markers RM 6100, RM 6344 and RM 1108 linked to Rf4 locus located on chromosome 10 and 7. Based on pollen fertility, 23 hybrids were found to be very effective restorers and 47 as partial restorers while, 44 hybrids were found to be very effective restorers and 26 hybrids showed partial restorer behavior based on spikelet fertility. The testers, MSN 71 and MSN 15- 16 behaved as partial restorers for all the CMS lines except CMS 2A. Based on pollen fertility, the lines CMS 5A and CMS 7A had highest number (4) of effective restorers, followed CMS 9A which had three effective restorers. The male parents, MSN 36, KMR 3, PBK 093-1 -4-4-2-1, PBK 095-5-4-5-1 and PBK 091 -3-7-1 -1 were classified as effective restorers for all the CMS lines.
\end{abstract}

All the article published by Journal of Experimental Biology and Agricultural Sciences is licensed under a Creative Commons Attribution-NonCommercial 4.0 International License Based on a work at www.jebas.org.

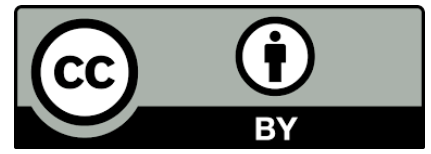




\section{Introduction}

Rice (Oryza sativa L.) is an important staple food crop for more than half of the world population including India. Over 90 per cent of the rice is produced and consumed in Asia accounting for more than 65 per cent of calorific intake (Khush, 2004). The Green revolution enabled the rice production to meet the growing demand of the increasing population and to maintain selfsufficiency thus helped many countries to escape from starvation (Sharma et al., 2013). The increase in production has to be achieved from 106.3 million tonnes to 120 million tonnes by the year 2020 without adversely affecting the environment has there is a drastic decline and deterioration of resources such as land, water and other inputs (Sharma et al., 2013).

In order to increase production with the pace of growing population, Chinese scientists successfully demonstrated the feasibility of exploiting hybrid vigour in rice by adopting three line system based on the cytoplasmic nuclear male sterility fertility restorer system (Hwa \& Yang, 2008). It has potential to bridge yield gap and to meet the challenge of increasing rice production while sustaining the natural resource base. Hybrid rice technology exploits the phenomenon of hybrid vigour (heterosis) to increase the yield potential of rice varieties by $15 \%$ to $20 \%$ over current commercial cultivars (Virmani \& Edwards, 1983; Hwa \& Yang, 2008). The commercial success of hybrid rice in China has clearly demonstrated the potential of this technology by yielding on an average of 1 to 1.5 tonnes more grain per hectare than the conventional high yielding varieties (Matthayatthaworn et al., 2011).

For developing high yielding heterotic hybrids, the first step is to identify restorers that can efficiently restore the fertility of $F_{1}$. The process of screening for the trait of fertility restoration is laborious and time consuming as it involves test crossing with a set of CMS lines and evaluation of $F_{1}$ for pollen and spikelet fertility. Identification of maintainer and restorer lines by observation of pollen fertility and spikelet fertility in test crosses involving CMS lines is the commonly practicsed traditional approach. In general, identification of different restorer lines for different CMS sources helps in increment of diversity.

Recently, molecular markers have also been successfully used by several researchers for the tagging of fertility restorer genes and classification of pollen parents into the categories of sterility maintainers and fertility restorers (Sheeba et al., 2009). The use of molecular markers linked to $R f$ genes can enhance the selection efficiency, save time and avoid the complications associated with phenotype-based screening. The fertility restorer genes $R f-3$ and $R f-4$ for WA-type CMS have been mapped on chromosome 1 and 10, respectively (Sheeba et al., 2009). The genes controlling fertility restoration do notbehave identically under different genetic backgrounds because of which different segregation ratios are obtained in different combinations of CMS and restorer lines.

In order to evolve hybrids that are superior in yield potential to the existing ones and adaptable in newer areas, one essential component of the requisite methodology is to identify newer potential restorer and maintainer lines from locally adopted material through systematic generation of new crosses and their proper evaluation. Therefore, there is a need to identify an effective restorer line having tightly linked $R f$ genes, so that marker aided selection can be used as a tool to identify restorers at an early stage of crop growth, there by such identified lines can be utilized to effect hybrids in the very present season. Keeping these points in view, present study was planned to characterize newly developed lines into maintainer and restorers based on floral fertility and SSR markers markers linked to fertility restorer gene.

\section{Material and Methods}

The experimental material comprised of 70 newly developed hybrids by crossing ten CMS lines (Table 1) along with seven testers (Table 2) in line $\times$ tester mating design at Hybrid rice

Table 1 List of CMS lines along with parentage and source of cytoplasm

\begin{tabular}{ccll|}
$\begin{array}{c}\text { Sl. } \\
\text { No }\end{array}$ & CMS lines & Parentage & $\begin{array}{c}\text { Cytoplasmic source } \\
\text { in CMS line } \\
\text { (A line) }\end{array}$ \\
\hline 1 & CMS 1A & KCMS 40A & CMS - WA \\
\hline 2 & CMS 2A & KCMS 48A & CMS - WA \\
\hline 3 & CMS 3A & IR 68888A/Pragathi & CMS - WA \\
\hline 4 & CMS 4A & IR 68902A/MSN- 20-12-1-2 & CMS - WA \\
\hline 5 & CMS 5A & IR 68896A/MSN 43 & CMS - WA \\
\hline 6 & CMS 6A & IR 68888A/IR 20 & CMS - WA \\
\hline 7 & CMS 7A & IR 68888A/MSN-20-13-1-1 & CMS - WA \\
\hline 8 & CMS 8A & IR 70369A/MSN 96 & CMS - WA \\
\hline 9 & CMS 9A & IR 70365A/IR 20 & CMS - WA \\
\hline 10 & CMS 10A & IR62829A/IR 30864 & CMS - WA \\
\hline
\end{tabular}

Table 2 List of testers used along with parentage

\begin{tabular}{|ccc|}
\hline S1. No & Testers & Parentage \\
\hline 1 & MSN - 36 & Selection from MRP 5180a \\
\hline 2 & KMR -3 & Jaya/IR 29723-143-3-2-1 \\
\hline 3 & MSN -71 & IR 9761/KMR 3R \\
\hline 4 & MSN -15-16 & Jyothi/ KMR 3R \\
\hline 5 & PBK 093-1-4-2-1 & IR60919/ MSN-36 \\
\hline 6 & PBK 095-5-4-5-1 & CRMS 32 B/Thanu \\
\hline 7 & PBK 091-3-7-1-1 & MSN- 98/ Athira \\
\hline
\end{tabular}


section, ZARS, V. C. Farm, Mandya , Karnataka, India during summer 2014. These seven testers were selected based on the pollen and spikelet fertility studies from 100 newly developed parental lines from earlier studies.

Leaf sample from all the male parents (Table 2) were used for DNA isolation and validation of SSR markers linked to fertility restoration (Rf) locus. Total genomic DNA was extracted from 35 days old seedling using CTAB (Cetyl Trimethyl Ammonium Bromide method) (Saghai-Maroof, 1984). Quality and quantity of extracted DNA was determined spectrophotometrically by taking absorbance at $260 \mathrm{~nm}$ and $280 \mathrm{~nm}$ (Varian Cary 50 Spectrophotometer). The extracted DNA samples were diluted using TE buffer to get the working concentration of $50 \mathrm{ng} / \mu \mathrm{l}$. The diluted DNA samples were used for SSR analysis.

Earlier reported tightly linked markers were used for genotyping of testers. List of SSR markers used in the study with their features is presented in Table 3. For SSR analysis PCR conditions were optimized as described previously (Panaud et al., 1996) with minor modifications. PCR amplification reaction were conducted in 20-25 ng of template DNA, $100 \mu \mathrm{M}$ of dNTPs, 100 pmohls of each of forward and reverse primer, $10 \mathrm{x}$ PCR buffer (10mMTris $\mathrm{pH} 8.0,50$ $\mathrm{mMKCl}, 1.8 \mathrm{mM} \mathrm{MgCl} 2$ and $0.01 \mathrm{mg} / \mathrm{ml}$ gelatin) and one unit of Taq DNA polymerase (Bangalore Genei, India) in a volume of $20 \mu \mathrm{l}$. One drop of mineral oil (Sigma) was dropped on each well of reaction mixture to avoid evaporation in the thermocycler. The PCR amplification was carried out using a thermocycler (Eppendorf) with an initial denaturation step of $94^{\circ} \mathrm{C}$ for $4 \mathrm{~min}$, followed by 35 cycles of denaturation $(1 \mathrm{~min}$ at $94^{\circ} \mathrm{C}$ ), annealing depending on the primers used (30 SEC at $\left.56^{\circ} \mathrm{C}\right)$ and extension $\left(2 \mathrm{~min}\right.$ at $\left.72^{\circ} \mathrm{C}\right)$. After the last cycle, a final extension was carried out for $7 \mathrm{~min}$ at $72^{\circ} \mathrm{C}$. The reproducibility of amplification products was checked twice for each primer. Amplified products were resolved by electrophoresis in $2.5 \%$ agarose gel containing 0.5 $\mu \mathrm{g} / \mathrm{mlethidium}$ bromides.Four $\mu \mathrm{l}$ of loading dye was added to
$20 \mu 1$ of PCR products and mixed well before loading into the wells.A $10 \mu 1$ of the PCR products were loaded into the wells, care was taken to prevent mixing of samples between the wells. A voltage of $1-5 \mathrm{v} / \mathrm{cm}$ was given for a time period of three hours for separation of PCR fragments. After electrophoresis, the DNA banding pattern was viewed under UV light and documented. The bands generated by microsatellite primers were given score $\mathrm{M}$ for maintainer alleles and $\mathrm{R}$ for restorer type alleles. CRMS 32B and MSN 36 were used as standard check for identification of maintainer and restorer allele, respectively.

These 70 hybrids developed were evaluated along with their parents and three standard checks viz., KRH-2, KRH-4 and GK 5013 which are high yielding medium duration hybrids. Seedlings were transplanted with a spacing of $20 \mathrm{~cm} \times 15 \mathrm{~cm}$ in single rows with single seedling per hill in a Randomized Complete Block Design (RCBD) with two replications during Kharif 2014. All the recommended package of practices was followed timely to ensure good crop establishment. Observations were recorded on five randomly selected competitive plants on pollen fertility $(\%)$ and spikelet fertility $(\%)$.

\subsection{Estimation of pollen fertility}

For pollen fertility (\%), three spikelets, one each from top, middle and bottom of main panicle of CMS lines each from two replications were collected and pollen grains were squeezed out from all the anthers on a clean glass slide and stained with 1.0 per cent I-KI (Iodine-Potassium Iodide) stain (which is prepared by dissolving $2 \mathrm{~g}$ of potassium iodide and $1 \mathrm{~g}$ of iodine in $100 \mathrm{ml}$ of distilled water) and examined under microscope at a magnification of 10X. The pollens were considered to be fertile if they were round, plumpy and deeply stained, while they were considered as sterile if they were shrunken, unstained and irregular in shape. Three microscopic fields were counted for each spikelet and pollen fertility was expressed in percentage.

Pollen fertility $(\%)=\frac{\text { Number of fertility (stained) pollen grains }}{\text { Total number of pollen grains }} \times 100$

Table 3 List of SSR markers used for validation of fertility restoration $(R f)$ locus in rice

\begin{tabular}{|ccccclc|}
\hline S1 No & Marker & Allele & Chromosome No & Genetic distance & \multicolumn{1}{c|}{ Sequence } & Reference \\
\hline 1 & RM1 & Rf3 & 1 & $5.6 \mathrm{cM}$ & $\begin{array}{l}\text { F: GCGAAAACACAATGCAAAAA } \\
\text { R: GCGTTGGTTGGACCTGAC }\end{array}$ & $\begin{array}{c}\text { Alavi et al. (2009) } \\
\text { Ahmadikhah et al.(2007) }\end{array}$ \\
\hline 2 & RM 6100 & Rf4 & 10 & $1.2 \mathrm{cM}$ & $\begin{array}{l}\text { F: TCCTCTACCAGTACCGCACC } \\
\text { R: GCTGGATCACAGATCATTGC }\end{array}$ & Sheeba et al. (2009) \\
\hline 3 & RM 6344 & Rf4 & 7 & $13.3 \mathrm{cM}$ & $\begin{array}{l}\text { F:ACACGCCATGGATGATGAC } \\
\text { R:TGGCATCATCACTTCCTCAC }\end{array}$ & Bazrkar et al. (2008) \\
\hline 4 & RM 1108 & Rf4 & 10 & $1.6 \mathrm{cM}$ & $\begin{array}{l}\text { F: GCTCGCGAATCAATCCAC } \\
\text { R: CTGGATCCTGGACAGACGAG }\end{array}$ & Sheeba et al. (2009) \\
\hline
\end{tabular}

Journal of Experimental Biology and Agricultural Sciences http://www.jebas.org 
The genotypes were grouped into four different classes based on pollen fertility per cent(Virmani et al., 1997).

\begin{tabular}{|clcl|}
\hline Sl.No & \multicolumn{1}{c}{ Class } & \multicolumn{1}{c|}{ Range } \\
\hline 1 & Maintainer (M) & 0 to 1.00 per cent \\
\hline 2 & Partial maintainer ( PM) & $:$ & 1.1 to 20.00 per cent \\
\hline 3 & Partial restorer (PR) & $:$ & 20.1 to 80.00 per cent \\
\hline 4 & Effective restorer (R) & $:$ & 80.1 to 100.00 per cent \\
\hline
\end{tabular}

\subsection{Estimation of spikelet fertility}

Spikelet fertility percent is the ratio of number of filled grains to total number of spikelets per panicle and expressed as percentage. Number of filled and chaffy spikelets in five main panicles of five selected plants in each replication were pooled together and averaged at the time of harvest to assess the spikelet fertility.

$$
\text { Spikelet fertility }(\%)=\frac{\text { Number of filled grains }}{\text { Total number of spikelets }} \times 100
$$

The genotypes were grouped into four different classes based on spikelet fertility per cent as shown under (Virmani et al., 1997).

\begin{tabular}{|clll|}
\hline Sl. No & \multicolumn{1}{c}{ Class } & \multicolumn{1}{c|}{ Range } \\
\hline 1 & Effective maintainer $(\mathrm{M})$ & $:$ & 0 to 5.00 per cent \\
\hline 2 & Partial maintainer $(\mathrm{PM})$ & $:$ & 5.1 to 20.00 per cent \\
\hline 3 & Partial restorer (PR) & $:$ & 20.1 to 70.00 per cent \\
\hline 4 & Effective restorer (R) & $:$ & 70.1 to 100.00 per cent \\
\hline
\end{tabular}

\section{Results and discussion}

Identification of maintainers and restorers is fundamental for the commercial exploitation of heterosis breeding programme using cytoplasmic male sterility (CMS) system (Sharma et al., 2012; Bhati,
2017). Restorers for different cytosterile sources will increase the cytoplasmic diversification, which in turn can prevent genetic vulnerability due to the use of single CMS source. Therefore, the present investigation was undertaken to identify maintainers and restorers based on molecular and floral characterization.

Staining patterns and shapes of pollen grains in genotypes possessing male sterility-inducing cytoplasm and sterility-maintaining nuclear gene(s) are known to be influenced by the developmental stage at which pollen abortion occurs and these developmental stages are related to nuclear stages (Chaudhary et al., 1981; Eikonin \& Tsvetova 2012). Based on staining pattern obtained, the pollen parents are classified as effective restorers (MSN 15-16) and partial restorers (PBK 095-5-4-5-1) (Figure 1). The highest pollen and spikelet fertility was observed in MSN -15-16 (92.68) and MSN - 36 (92.75) respectively (Table 4).

Four reported SSR markers linked (Table 3) to fertility locus ( $R f$ ) were used to screen the seven male parents with CRMS 32B and MSN 36 as standard for maintainer and restorer allele respectively. All the four markers (RM 1, RM 6100, RM 6344 and RM1108) exhibited polymorphism between standard restorer

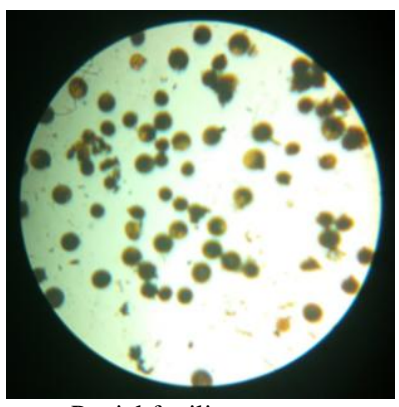

Partial fertility restorer

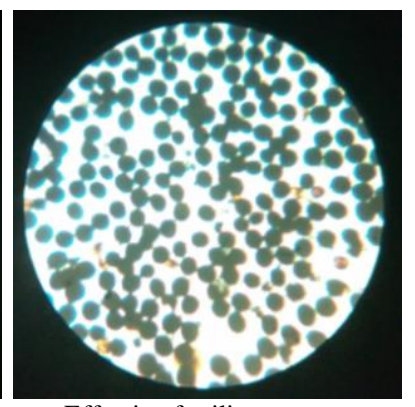

Effective fertility restorer
Figure 1 Pollen fertility restoration patterns in testers. The harvested panicles were fixed in acetone: alcohol (1:3) solution. Anthers were smeared in solution congaing $0.5 \%$ iodine in $2 \%$ potassium iodide and examined under light microscope.

Table 4 Phenotypic and genotypic scoring of testers based on pollen fertility, spikelet fertility and for four SSR markers

\begin{tabular}{|c|c|c|c|c|c|c|c|c|c|}
\hline \multirow[b]{2}{*}{ Sl. No } & \multirow[b]{2}{*}{ Genotypes } & \multicolumn{4}{|c|}{ Phenotypic scoring } & \multicolumn{4}{|c|}{ Genotypic scoring } \\
\hline & & $\begin{array}{l}\text { Pollen } \\
\text { Per cent }\end{array}$ & $\begin{array}{l}\text { rtility } \\
\text { Class }\end{array}$ & $\begin{array}{l}\text { Spikelet } \\
\text { Per cent }\end{array}$ & $\begin{array}{l}\text { tility } \\
\text { Class }\end{array}$ & RM 1 & RM 6100 & RM 6344 & RM 1108 \\
\hline 1 & MSN - 36 & 90.37 & $\mathrm{R}$ & 92.75 & $\mathrm{R}$ & $\mathrm{R}$ & $\mathrm{R}$ & $\mathrm{R}$ & $\mathrm{R}$ \\
\hline 2 & KMR -3 & 85.86 & $\mathrm{R}$ & 79.84 & $\mathrm{R}$ & $\mathrm{R}$ & $\mathrm{R}$ & $\mathrm{R}$ & $\mathrm{R}$ \\
\hline 3 & MSN -71 & 87.80 & $\mathrm{R}$ & 84.51 & $\mathrm{R}$ & $\mathrm{R}$ & $\mathrm{R}$ & $\mathrm{R}$ & $\mathrm{R}$ \\
\hline 4 & MSN -15-16 & 92.68 & $\mathrm{R}$ & 90.12 & $\mathrm{R}$ & $\mathrm{R}$ & $\mathrm{R}$ & $\mathrm{R}$ & $\mathrm{R}$ \\
\hline 5 & PBK 093-1-4-4-2-1 & 92.50 & $\mathrm{R}$ & 88.33 & $\mathrm{R}$ & $\mathrm{R}$ & $\mathrm{R}$ & $\mathrm{R}$ & $\mathrm{R}$ \\
\hline 6 & PBK 095-5-4-5-1 & 74.12 & PR & 70.61 & $\mathrm{R}$ & $\mathrm{R}$ & M & $\mathrm{R}$ & $\mathrm{R}$ \\
\hline 7 & PBK 091-3-7-1-1 & 86.78 & $\mathrm{R}$ & 81.34 & $\mathrm{R}$ & $\mathrm{R}$ & $\mathrm{R}$ & $\mathrm{R}$ & $\mathrm{R}$ \\
\hline
\end{tabular}

Note: R- Restorer PR- Partial restorer

Journal of Experimental Biology and Agricultural Sciences http://www.jebas.org 
(MSN 36) and maintainer (CRMS 32B) (Table 4, Figure 2). The allelic pattern of all the four polymorphic markers was compared with phenotypic reaction of fertility based on pollen fertility and spikelet fertility across CMS lines. Allthe four markers (RM 1, RM 6100, RM 6344 and RM 1108) showed highly positive association with phenotypic fertility restoration and maintainer type allele (Table 5). The markers RM 6100, RM 6344 and RM 1108 are linked to Rf4 locus which is located on chromosome 10 and 7 reported by Sheeba et al. (2009) and Bazrkar et al. (2008), respectively and RM 1 linked to $R f 3$ locus which is located on

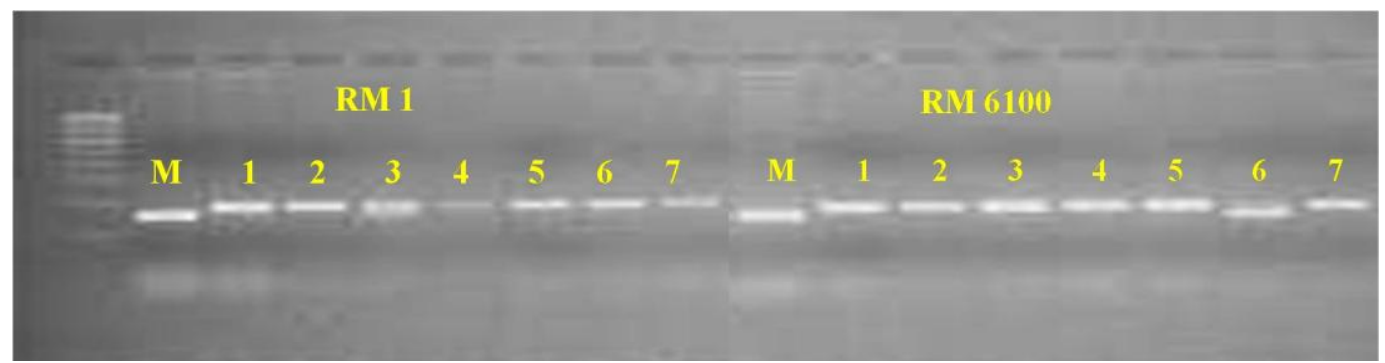

\section{RM1108}
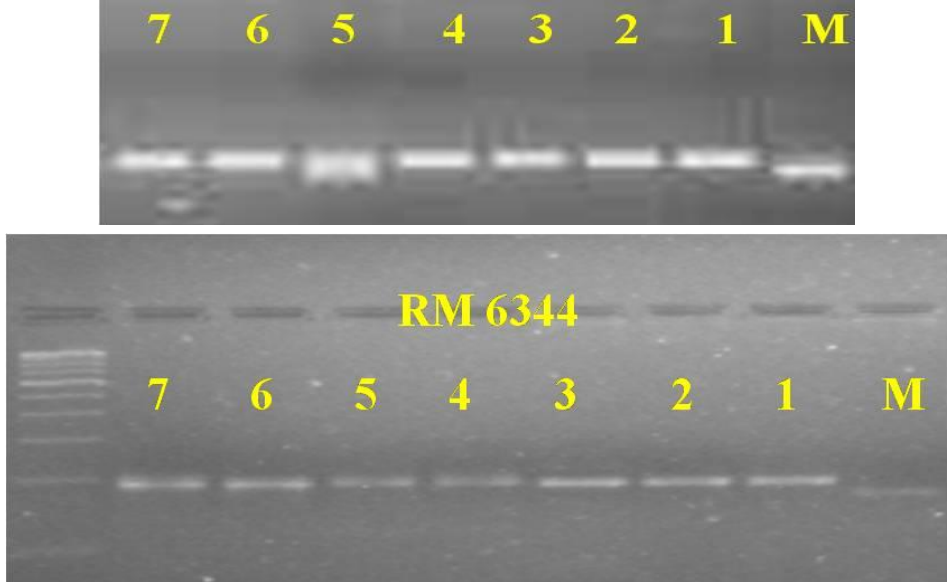

M-CRMS 32B (maintainer), 1: MSN-36, 2: KMR-3, 3:MSN - 71, 4:MSN-15-16, 5:PBK 093-1-4-4-2-1, 6:PBK 095-5-4-5-1, 7:PBK 091-3-7-1-1

Figure 2 Screening of polymorphic markers across the male parent

Table 5 Association of marker allele with the phenotype based on pollen/spikelet fertility across ten CMS lines

\begin{tabular}{|c|c|c|c|c|c|c|c|c|c|c|c|c|c|c|c|}
\hline Sl. & & CMS & CMS & CMS & CMS & CMS & CMS & CMS & CMS & CMS & CMS & \multicolumn{4}{|c|}{ Genotypic scoring } \\
\hline No & 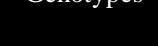 & $1 \mathrm{~A}$ & $2 \mathrm{~A}$ & $3 \mathrm{~A}$ & $4 \mathrm{~A}$ & $5 \mathrm{~A}$ & $6 \mathrm{~A}$ & $7 \mathrm{~A}$ & $8 \mathrm{~A}$ & $9 \mathrm{~A}$ & $10 \mathrm{~A}$ & RM1 & RM 6100 & RM 6344 & RM 1108 \\
\hline 1 & $\mathrm{MSN}-36$ & $\mathrm{PR} / \mathrm{R}$ & $\mathrm{R}$ & PR & $\mathrm{PR} / \mathrm{R}$ & $\mathrm{R}$ & $\mathrm{PR} / \mathrm{R}$ & $\mathrm{R}$ & $\mathrm{PR} / \mathrm{R}$ & $\mathrm{R}$ & $\mathrm{PR} / \mathrm{R}$ & $\mathrm{R}$ & $\mathrm{R}$ & $\mathrm{R}$ & $\mathrm{R}$ \\
\hline 2 & KMR -3 & $\mathrm{R}$ & $\mathrm{R}$ & $\mathrm{R}$ & $\mathrm{PR} / \mathrm{R}$ & $\mathrm{PR} / \mathrm{R}$ & PR & PR & PR & $\mathrm{PR} / \mathrm{R}$ & $\mathrm{R}$ & $\mathrm{R}$ & $\mathrm{R}$ & $\mathrm{R}$ & $\mathrm{R}$ \\
\hline 3 & MSN -71 & PR & $\mathrm{R}$ & PR & PR & PR & PR & PR & PR & PR & PR & $\mathrm{R}$ & $\mathrm{R}$ & $\mathrm{R}$ & $\mathrm{R}$ \\
\hline 4 & MSN -15-16 & PR & $\mathrm{R}$ & PR & PR & $\mathrm{PR} / \mathrm{R}$ & PR & PR & PR & PR & PR & $\mathrm{R}$ & $\mathrm{R}$ & $\mathrm{R}$ & $\mathrm{R}$ \\
\hline 5 & PB $1-4-4-2-1$ & $\mathrm{PR} / \mathrm{R}$ & $\mathrm{PR} / \mathrm{R}$ & PR & $\mathrm{R}$ & $\mathrm{R}$ & $\mathrm{PR} / \mathrm{R}$ & $\mathrm{R}$ & $\mathrm{R}$ & $\mathrm{PR} / \mathrm{R}$ & PR & $\mathrm{R}$ & $\mathrm{R}$ & $\mathrm{R}$ & $\mathrm{R}$ \\
\hline 6 & PB 5-4-5-1 & $\mathrm{PR} / \mathrm{R}$ & $\mathrm{R}$ & $\mathrm{PR} / \mathrm{R}$ & $\mathrm{PR} / \mathrm{R}$ & $\mathrm{R}$ & $\mathrm{PR} / \mathrm{R}$ & $\mathrm{R}$ & PR & $\mathrm{R}$ & $\mathrm{R}$ & $\mathrm{R}$ & $\mathrm{M}$ & $\mathrm{R}$ & $\mathrm{R}$ \\
\hline 7 & PB 3-7-1-1 & PR & PR & $\mathrm{PR} / \mathrm{R}$ & $\mathrm{R}$ & $\mathrm{R}$ & $\mathrm{PR} / \mathrm{R}$ & $\mathrm{R}$ & $\mathrm{PR} / \mathrm{R}$ & $\mathrm{R}$ & $\mathrm{PR} / \mathrm{R}$ & $\mathrm{R}$ & $\mathrm{R}$ & $\mathrm{R}$ & $\mathrm{R}$ \\
\hline
\end{tabular}

M- Maintainer R- Restorer PR- Partial restorer PM- Partial maintainer

Journal of Experimental Biology and Agricultural Sciences http://www.jebas.org 
chromosome 1 reported by Alavi et al. (2009) and Ahmadikhah et al. (2007). These results indicated that Rf3 and Rf4 locus are the predominant restoration alleles for CMS lines studied.

Seventy hybrids produced by crossing promising ten CMS lines with seven male parents which were selected from parental lines based on spikelet fertility and pollen selection and reported markers linked to $R f$ locus were evaluated during Kharif 2014. The results obtained based on pollen and spikelet fertility is presented in Table 6 . The genotypes were classified as maintainer, restorer, partial maintainer and partial restorer based on pollen and spikelet fertility. Based on pollen fertility, 23 hybrids were found to be very effective restorers and 47 as partial restorers. The testers, MSN 71 and MSN 15-16 behaved as partial restorers for all the CMS lines except CMS 2A. Based on spikelet fertility, 44 hybrids were found very effective restorers and 26 hybrids showed partial restorer behavior (Table 6).

Table 6 Classification of crosses into restorers and maintainers based on pollen fertility and spikelet fertility

\begin{tabular}{|c|c|c|c|c|c|c|}
\hline \multirow{2}{*}{ S1. No } & \multirow{2}{*}{ Hybrids } & \multicolumn{2}{|c|}{ Pollen fertility } & \multicolumn{2}{|c|}{ Spikelet fertility } & \multirow{2}{*}{ Based on both } \\
\hline & & Percent & Class & Percent & Class & \\
\hline 1 & CMS $1 \mathrm{~A} \times \mathrm{MSN} 36$ & 76.22 & PR & 71.71 & $\mathrm{R}$ & $\mathrm{PR} / \mathrm{R}$ \\
\hline 2 & CMS $1 \mathrm{~A} \times \mathrm{KMR}-3$ & 94.06 & $\mathrm{R}$ & 90.80 & $\mathrm{R}$ & $\mathrm{R}$ \\
\hline 3 & CMS $1 \mathrm{~A} \times \mathrm{MSN}-71$ & 35.97 & PR & 27.10 & PR & PR \\
\hline 4 & CMS $1 \mathrm{~A} \times \mathrm{MSN}-15-16$ & 62.15 & PR & 57.10 & PR & PR \\
\hline 5 & CMS 1A $\times$ PB 1-4-4-2-1 & 77.85 & PR & 75.05 & $\mathrm{R}$ & $\mathrm{PR} / \mathrm{R}$ \\
\hline 6 & CMS $1 \mathrm{~A} \times$ PB 5-4-5-1 & 79.26 & PR & 74.78 & $\mathrm{R}$ & $\mathrm{PR} / \mathrm{R}$ \\
\hline 7 & CMS $1 \mathrm{~A} \times \mathrm{PB} 3-7-1-1$ & 69.02 & PR & 61.92 & PR & PR \\
\hline 8 & CMS $2 \mathrm{~A} \times \mathrm{MSN} 36$ & 84.94 & $\mathrm{R}$ & 81.95 & $\mathrm{R}$ & $\mathrm{R}$ \\
\hline 9 & CMS $2 \mathrm{~A} \times \mathrm{KMR}-3$ & 82.09 & $\mathrm{R}$ & 72.13 & $\mathrm{R}$ & $\mathrm{R}$ \\
\hline 10 & CMS 2A $\times$ MSN -71 & 84.08 & $\mathrm{R}$ & 81.79 & $\mathrm{R}$ & $\mathrm{R}$ \\
\hline 11 & CMS $2 \mathrm{~A} \times \mathrm{MSN}-15-16$ & 80.02 & $\mathrm{R}$ & 74.10 & $\mathrm{R}$ & $\mathrm{R}$ \\
\hline 12 & CMS $2 \mathrm{~A} \times \mathrm{PB} 1-4-4-2-1$ & 78.99 & PR & 74.02 & $\mathrm{R}$ & $\mathrm{PR} / \mathrm{R}$ \\
\hline 13 & CMS 2A $\times$ PB 5-4-5-1 & 87.43 & $\mathrm{R}$ & 83.99 & $\mathrm{R}$ & $\mathrm{R}$ \\
\hline 14 & CMS $2 \mathrm{~A} \times \mathrm{PB} 3-7-1-1$ & 63.99 & PR & 56.90 & PR & PR \\
\hline 15 & CMS $3 \mathrm{~A} \times \mathrm{MSN} 36$ & 66.01 & PR & 56.90 & PR & PR \\
\hline 16 & CMS $3 \mathrm{~A} \times \mathrm{KMR}-3$ & 96.15 & $\mathrm{R}$ & 92.00 & $\mathrm{R}$ & $\mathrm{R}$ \\
\hline 17 & CMS 3A $\times$ MSN -71 & 32.78 & PR & 22.79 & PR & PR \\
\hline 18 & CMS $3 \mathrm{~A} \times \mathrm{MSN}-15-16$ & 63.05 & PR & 60.05 & PR & PR \\
\hline 19 & CMS $3 \mathrm{~A} \times$ PB 1-4-4-2-1 & 63.11 & PR & 59.95 & PR & PR \\
\hline 20 & CMS 3A $\times$ PB 5-4-5-1 & 74.06 & PR & 70.93 & $\mathrm{R}$ & $\mathrm{PR} / \mathrm{R}$ \\
\hline 21 & CMS $3 \mathrm{~A} \times \mathrm{PB} 3-7-1-1$ & 73.20 & PR & 71.17 & $\mathrm{R}$ & $\mathrm{PR} / \mathrm{R}$ \\
\hline 22 & CMS 4A $\times$ MSN 36 & 77.06 & PR & 73.83 & $\mathrm{R}$ & $\mathrm{PR} / \mathrm{R}$ \\
\hline 23 & CMS $4 \mathrm{~A} \times \mathrm{KMR}-3$ & 76.17 & PR & 71.00 & $\mathrm{R}$ & $\mathrm{PR} / \mathrm{R}$ \\
\hline 24 & $\mathrm{CMS} 4 \mathrm{~A} \times \mathrm{MSN}-71$ & 69.15 & PR & 63.05 & PR & PR \\
\hline 25 & CMS $4 \mathrm{~A} \times \mathrm{MSN}-15-16$ & 29.23 & PR & 22.83 & PR & PR \\
\hline 26 & CMS 4A $\times$ PB 1-4-4-2-1 & 90.90 & $\mathrm{R}$ & 87.14 & $\mathrm{R}$ & $\mathrm{R}$ \\
\hline 27 & CMS 4A $\times$ PB 5-4-5-1 & 72.86 & PR & 70.97 & $\mathrm{R}$ & $\mathrm{PR} / \mathrm{R}$ \\
\hline 28 & CMS 4A $\times$ PB 3-7-1-1 & 92.05 & $\mathrm{R}$ & 86.05 & $\mathrm{R}$ & $\mathrm{R}$ \\
\hline 29 & CMS 5A $\times$ MSN 36 & 89.15 & $\mathrm{R}$ & 84.96 & $\mathrm{R}$ & $\mathrm{R}$ \\
\hline 30 & CMS $5 \mathrm{~A} \times \mathrm{KMR}-3$ & 73.03 & PR & 71.05 & $\mathrm{R}$ & $\mathrm{PR} / \mathrm{R}$ \\
\hline 31 & CMS $5 \mathrm{~A} \times \mathrm{MSN}-71$ & 46.55 & PR & 30.98 & PR & $\mathrm{PR}$ \\
\hline 32 & CMS $5 \mathrm{~A} \times \mathrm{MSN}-15-16$ & 76.93 & PR & 73.08 & $\mathrm{R}$ & $\mathrm{PR} / \mathrm{R}$ \\
\hline
\end{tabular}

M- Maintainer, R- Restorer, PR- Partial restorer, PM- Partial maintainer 
Table 6: Contd.

\begin{tabular}{|c|c|c|c|c|c|c|}
\hline \multirow{2}{*}{ Sl. No } & \multirow{2}{*}{ Hybrids } & \multicolumn{2}{|c|}{ Pollen fertility } & \multicolumn{2}{|c|}{ Spikelet fertility } & \multirow{2}{*}{ Based on both } \\
\hline & & Percent & Class & Percent & Class & \\
\hline 33 & CMS 5A $\times$ PB 1-4-4-2-1 & 90.94 & $\mathrm{R}$ & 85.10 & $\mathrm{R}$ & $\mathrm{R}$ \\
\hline 34 & CMS 5A $\times$ PB 5-4-5-1 & 91.95 & $\mathrm{R}$ & 89.08 & $\mathrm{R}$ & $\mathrm{R}$ \\
\hline 35 & CMS 5A $\times$ PB 3-7-1-1 & 86.95 & $\mathrm{R}$ & 81.32 & $\mathrm{R}$ & $\mathrm{R}$ \\
\hline 36 & CMS 6A $\times$ MSN 36 & 78.06 & PR & 71.33 & $\mathrm{R}$ & $\mathrm{PR} / \mathrm{R}$ \\
\hline 37 & CMS 6A $\times$ KMR -3 & 38.55 & PR & 31.02 & PR & PR \\
\hline 38 & CMS $6 \mathrm{~A} \times \mathrm{MSN}-71$ & 35.13 & PR & 24.93 & PR & PR \\
\hline 39 & CMS 6A $\times$ MSN $-15-16$ & 37.23 & PR & 30.08 & PR & PR \\
\hline 40 & CMS $6 \mathrm{~A} \times \mathrm{PB} 1-4-4-2-1$ & 70.42 & PR & 71.13 & $\mathrm{R}$ & $\mathrm{PR} / \mathrm{R}$ \\
\hline 41 & CMS 6A $\times$ PB 5-4-5-1 & 75.18 & PR & 70.00 & $\mathrm{R}$ & $\mathrm{PR} / \mathrm{R}$ \\
\hline 42 & CMS 6A $\times$ PB 3-7-1-1 & 76.43 & PR & 70.23 & $\mathrm{R}$ & $\mathrm{PR} / \mathrm{R}$ \\
\hline 43 & CMS 7A $\times$ MSN 36 & 84.99 & $\mathrm{R}$ & 77.96 & $\mathrm{R}$ & $\mathrm{R}$ \\
\hline 44 & CMS 7A $\times$ KMR -3 & 34.83 & PR & 25.01 & PR & PR \\
\hline 45 & CMS 7A $\times$ MSN -71 & 36.22 & PR & 25.08 & PR & PR \\
\hline 46 & CMS 7A $\times$ MSN -15-16 & 72.16 & PR & 66.03 & PR & PR \\
\hline 47 & CMS 7A $\times$ PB 1-4-4-2-1 & 89.99 & $\mathrm{R}$ & 83.90 & $\mathrm{R}$ & $\mathrm{R}$ \\
\hline 48 & CMS 7A $\times$ PB 5-4-5-1 & 96.02 & $\mathrm{R}$ & 92.92 & $\mathrm{R}$ & $\mathrm{R}$ \\
\hline 49 & CMS 7A $\times$ PB 3-7-1-1 & 89.33 & $\mathrm{R}$ & 84.98 & $\mathrm{R}$ & $\mathrm{R}$ \\
\hline 50 & CMS 8A $\times$ MSN 36 & 72.02 & PR & 70.32 & $\mathrm{R}$ & $\mathrm{PR} / \mathrm{R}$ \\
\hline 51 & CMS $8 \mathrm{~A} \times \mathrm{KMR}-3$ & 72.10 & PR & 64.99 & PR & PR \\
\hline 52 & CMS $8 \mathrm{~A} \times \mathrm{MSN}-71$ & 31.96 & PR & 24.80 & PR & PR \\
\hline 53 & CMS $8 \mathrm{~A} \times \mathrm{MSN}-15-16$ & 29.85 & PR & 23.05 & PR & PR \\
\hline 54 & CMS 8A $\times$ PB 1-4-4-2-1 & 84.97 & $\mathrm{R}$ & 82.25 & $\mathrm{R}$ & $\mathrm{R}$ \\
\hline 55 & CMS $8 \mathrm{~A} \times$ PB 5-4-5-1 & 35.70 & PR & 25.95 & PR & PR \\
\hline 56 & CMS $8 \mathrm{~A} \times \mathrm{PB} 3-7-1-1$ & 72.72 & PR & 70.99 & $\mathrm{R}$ & $\mathrm{PR} / \mathrm{R}$ \\
\hline 57 & CMS 9A × MSN 36 & 80.04 & $\mathrm{R}$ & 74.20 & $\mathrm{R}$ & $\mathrm{R}$ \\
\hline 58 & CMS 9A $\times$ KMR -3 & 74.99 & PR & 70.98 & $\mathrm{R}$ & $\mathrm{PR} / \mathrm{R}$ \\
\hline 59 & CMS 9A $\times$ MSN -71 & 31.96 & PR & 21.84 & PR & PR \\
\hline 60 & CMS 9A $\times$ MSN $-15-16$ & 66.98 & PR & 54.75 & PR & PR \\
\hline 61 & CMS 9A $\times$ PB 1-4-4-2-1 & 70.80 & PR & 70.94 & $\mathrm{R}$ & $\mathrm{PR} / \mathrm{R}$ \\
\hline 62 & CMS 9A $\times$ PB 5-4-5-1 & 89.15 & $\mathrm{R}$ & 87.05 & $\mathrm{R}$ & $\mathrm{R}$ \\
\hline 63 & CMS 9A $\times$ PB 3-7-1-1 & 85.94 & $\mathrm{R}$ & 78.88 & $\mathrm{R}$ & $\mathrm{R}$ \\
\hline 64 & CMS 10A $\times$ MSN 36 & 71.93 & PR & 71.33 & $\mathrm{R}$ & $\mathrm{PR} / \mathrm{R}$ \\
\hline 65 & CMS $10 \mathrm{~A} \times \mathrm{KMR}-3$ & 86.01 & $\mathrm{R}$ & 79.79 & $\mathrm{R}$ & $\mathrm{R}$ \\
\hline 66 & CMS 10A $\times$ MSN -71 & 52.50 & PR & 42.05 & PR & PR \\
\hline 67 & CMS $10 \mathrm{~A} \times \mathrm{MSN}-15-16$ & 29.90 & PR & 25.18 & PR & PR \\
\hline 68 & CMS $10 \mathrm{~A} \times$ PB $1-4-4-2-1$ & 32.89 & PR & 24.03 & PR & PR \\
\hline 69 & CMS $10 \mathrm{~A} \times \mathrm{PB} 5-4-5-1$ & 91.10 & $\mathrm{R}$ & 88.17 & $\mathrm{R}$ & $\mathrm{R}$ \\
\hline 70 & CMS $10 \mathrm{~A} \times \mathrm{PB} 3-7-1-1$ & 76.00 & PR & 71.76 & $\mathrm{R}$ & $\mathrm{PR} / \mathrm{R}$ \\
\hline
\end{tabular}

M- Maintainer, R- Restorer, PR- Partial restorer, PM- Partial maintainer

Journal of Experimental Biology and Agricultural Sciences http://www.jebas.org 
Based on pollen fertility, the lines CMS 5A and CMS 7A had highest number (4) of effective restorers, followed CMS 9A which had three effective restorers. While, the lines CMS 1A, CMS 3A and CMS 8A had least number of restorers (one) and CMS 6A had all partial restorers. Based on spikelet fertility, CMS 2A and CMS 5A had highest number (6) of restorers followed by CMS 4A and CMS 9A had five effective restorers each. CMS 1A, CMS 6A, CMS 7A and CMS 10A as they had four effective restorers each. The male parents, MSN 36, KMR 3, PBK 093-1 4-4-2-1, PBK 095-5-4-5-1and PBK 091 -3-7-1 -1 were classified as effective restorers for all the CMS lines and MSN 71 and MSN 15-16 showed partial restoration (Table 5).

However, majority of male parents restored complete fertility in CMS 2A followed by CMS 5A and CMS 7A. The effective restorers, identified in this study could be used to develop hybrids for commercial purpose. The results also proved the effectiveness of marker aided selection of restorers as most of testers selected produced perfect restoration in hybrids. However, problem of partial restoration need to be solved. Similar opinion was given by Rosamma \& Vijaykumar (2005).

\section{Conclusion}

The results clearly indicated that, fertility restoration reaction of the genotypes varies with genetic background of CMS lines. The identified maintainers and restorers are locally adopted. The identified restorer lines can be used as pollen parent in developing new commercial hybrid varieties in rice breeding programme. It is also proven from the results that markers are more effective and precise in selection of restorers as most of testers selected produced perfect restoration in hybrids.

\section{Conflicts of interest}

The authors declare that there is no conflict of interest for the contents of the manuscript.

\section{Reference}

Ahmadikhan A, Karlov GI, Nematzaden GH, Bezdi K, Ghasemi (2007) Inheritance of the fertility restoration and genotyping of rice lines of the restoring fertility Rf1 locusing molecular markers. International Journal of Plant Production 1:14-21.

Alavi M, Ahamadidhan A, KamkarB, Kalateh M, (2009) Mapping Rf3 locus in rice by SSR and CAPS markers. International Journal of Genetics and Molecular Biology 7:121 -126.

Bazrkar L, Ali AJ, Babaeian NA, Ebadi AA, Allangholipour M, Kazemitabar K, Nemazaden G, (2008) Tagging of four fertility restorer loci for wild abortive cytoplasmic male sterile system in rice (Oryza sativa L.) using microsatellite emarkers. Euphytica 164:669-677.
Bhati PK (2017) Identification of restorers and maintainers for different wild abortive cytoplasmic male sterile lines in rice (Oryza sativa L.). Bangladesh Journal of Botany 46 : 607-614.

Chaudhury RC, Virmani SS, Khush GS (1981) Pattern ofpollen abortion in same cytogenetic male sterile lines ofrice.Oryza18:140-142.

Eikonin LA, Tsvetova MI (2012) Heritable effect of plant water availability conditions restoration of male fertility in the "9E" CMSinducing cytoplasm of sorghum. Frontiers in Plant Science 3:91.

Hwa CM, Yang XC (2008) fixation of hybrid vigor in rice:Opportunities and challenges. Euphytica 160:287-293.

Khush GS (2004) What it will take to feed 2.0 billion rice consumers in 2030. Plant Molecular Biology 59:1-6.

Matthayatthaworn W, Sripichitt P, Phumichai C, Rungmekarat S, Uckarach S, Sreewongchai T (2011) Development of specific simple sequence repeat (SSR)markers for non-pollen type thermo-sensitive genic male sterile gene in rice (Oryza sativa L.). African Journal of Biotechnology 73:16437-16442.

Panaud O, Cheng O, McCouch SR (1996) Development of microsatellite markers and characterization of simple sequence length polymorphism (SSLP) in rice (Oryza sativa L.). Molecular Genetics and Genomics 252: 597-607.

Rosamma CA, Vijayakumar NK (2005) Maintainers and restores for CMS lines of rice. Journal of Tropical Agriculture 2:75-77.

Saghai-Maroof MA, Soliman KM, Jorgensen RA, Allard RW (1984) Ribosomal DNA spacer-length polymorphisms in barley: Mendelian inheritance, chromosomal location, and population dynamics. Proceedings of the National Academy of Sciences 81:8014-8018.

Sharma D, Sanghera GS, Sahu P, Sahu P, Parikh M,Sharma B, Bhandarkar S, Chaudhari PR, Binod, Jena BK (2013) Tailoring rice plants for sustainable yield through ideotype breeding and physiological interventions. African Journal of Agricultural Research 40:5004-5019.

Sharma SK, Singh SK, Nandan R, Kumar M (2012)Identification of Restorers and Maintainers for CMS lines of Rice (Oryza sativa L.). Indian Journal of Plant Genetic Resources 2:186-188.

Sheeba NK, Viraktamath BC, Sivaramakrishnan S,Gangasethi MG, Khera P, Sundaram RM (2009) Validationof molecular markers linked to fertility restorers for WACMS lines of rice. Euphytica167:217-227.

Virmani SS, Edwands IB (1983) Current status and futureprospects for breeding hybrid rice and wheat. Advances in Agronomy 36:145-214.

Virmani SS, Viraktamath BC, Casal CL, Toledo RS, Lopez MT, Manalo JO (1997) Hybrid rice breeding manual, International Rice Research Institute, Philippines. 